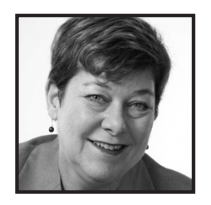

\title{
Commentary \\ We Are a Global Community: What if We Collaborated?
}

Julie Lindsay

\section{ABSTRACT}

Connected and collaborative learning that leads to co-creation of ideas and solutions is imperative across all levels of education. To make the shift we want to see, we need to understand the pedagogy of online learning in a global context. This commentary shares an understanding of thought leaders who have developed and shared new approaches that take learning beyond the immediate environment scaffolded by digital technologies. It also poses the question, "What if we collaborated as a global community?" and starts a conversation about new pedagogical approaches to support "flat," connected learning. This is already happening now - the future is nowit's time to connect the world.

"We are witnessing the birth of the world's truly global civilization." (Gore, 2013)

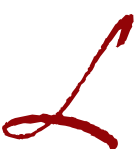

earning does not happen in isolation and modern learning involves the use of digital technology to learn with others in a multitude of ways. Despite Friedman's "flatteners" that brought world attention to the way emerging technologies are changing the global paradigm for communication and collaboration (Friedman, 2007), and despite organizations like the New Media Consortium (http://www.nmc.org/) providing updated material on emerging technologies and global implementations, educators and education institutions are yet to successfully shift from local to global learning modes. 
"Rather than being places students can learn about the world, schools are now places students can learn with the world." (Paterson, 2013)

This commentary focuses on online global collaborative learning. It will share insights into the research, practices, and pedagogies that are starting to transform learning to include a global environment-within and beyond systems, communities, education levels, and countries. The goal is to provide a starting point to vital conversations that will continue to lead to new educational approaches and actions for improved global learning.

\section{My Global Journey}

My authority to comment on the state of global collaborative learning stems from my experience as an international educator and a global educator and collaborator. As an international educator, originally from and now based again in Australia, I have lived and worked in K-12 education as a classroom teacher and educational technology and curriculum leader in six different countries across Australian, British, and International Baccalaureate systems. As a global educator, I have a mindset and skill set that allows me to design and implement online global collaborative projects for $\mathrm{K}-12$ students and bring teachers together in global communities to support better understanding of global learning and collaboration. As a global education researcher, I am completing my doctorate with a focus on online global collaborative educators and pedagogical change. I currently work for Charles Sturt University as an Adjunct at the master's degree level (with online students coming from across the world) and as a Quality Learning and Teaching Leader in online learning for the Faculty of Arts and Education. My perspectives and opinions in this commentary are based on all these experiences and dispositions. It is through 20 plus years of connecting with the world myself, connecting my students, and connecting my colleagues that has brought me to this point.

\section{Kuwait-A Story of Reaching Out to a Global Network}

Before we delve into other important topics I wish to share a story with you. As an international educator, I spent five years in the Middle East in Kuwait and Qatar. My experience in Kuwait was in the early 2000s and included the second Gulf War (which is another story in itself). Kuwait is a country with juxtaposition of culturesArabic and many expatriate guests. The international school I worked in was a 
"national" international school in that it had a 99\% Arabic clientele, and typical of the region in wanting local students to have an international English speaking education. This school had a non-collaborative working and learning environment, was exam focused, and quite stifling in many ways. No true collaborative working environment existed for me, therefore I had to reach out and make sure I connected beyond the school, and beyond the country to continue to grow as an educator. One action I took was to start a Masters degree specializing in educational technology leadership through George Washington University (DC), which was totally online-perfect for me! I remember one subject I completed at the time was Education Policy, which almost did my head in! There I was, an Australian teaching the British curriculum in a Kuwait national/international school studying American education policy—talk about globalization...?

A strong message here is that if the immediate learning environment is not conducive to the needs of the learner, virtual opportunities, both synchronous and asynchronous, provide networks and communities to engage with, contribute to, and collaborate with. This is one example where true global and collaborative learning is vital.

\section{Connected and Collaborative Learning- Essential Understandings}

\section{Connected Learning}

Connected learning makes use of new technology tools to build online networks and develop personal learning resources through interaction with personal learning networks and professional learning communities (Siemens, 2005). It is influenced by the need for pedagogies that are more personal, social, and participatory, with special reference to Web 2.0 tools (McLoughlin \& Lee, 2010) and provides infrastructure for online global collaboration as a pedagogical approach that includes the use of technology. It relates to and is heavily influenced by connectivism theory (Downes, 2006; 2007; Siemens, 2005; 2006).

Connectivism is often described as the learning theory for the digital age and is based on the use of networks and nodes to create connections and develop a personal learning network (Downes, 2014). The term "connectivism" describes a form of knowledge and pedagogy based on the idea that knowledge is distributed 
across networks of connections and that learning consists of the ability to construct and traverse those networks (Downes, 2008). The notion of connectivism and a connected learning ecology is relevant to this commentary in terms of the fluidity of technology-supported learning as individuals connect and learn across different settings, interests, and times.

\section{Collaborative Learning}

Collaboration is not a new pedagogy for learning, and much has been researched and written about this practice including the work of Dillenbourg (1999). In the broadest sense, "collaborative learning" is a situation in which two or more people learn or attempt to learn something together. As distinct from cooperative learning where the required tasks are distributed amongst the learners (Laurillard, 2009), in the collaborative learning process learners share and discuss and build on the outputs of their peers or collaborative partners.

Collaboration, the building of something through participation and negotiation with partners, is pedagogically valuable because, "coordination helps to manage the process to its conclusion, the continued attempt suggests iteration, to construct means the learners are developing their ideas, and a shared conception means they have to agree which is what drives the iteration" (Laurillard, 2012, pp. 187-188). In the current context, collaborative learning makes use of interactive technologies, is informed by the work of Piaget (1929) and Vygotsky (1978), and combines the social and construction elements of the learning process (Laurillard, 2009), emphasizing the importance of construction of a model or object.

Fullan, Langworthy, and Barber (2014) share collaboration as a "deep learning task" and skill for the future and state,

Collaboration in learning is easy to consider on the surface, but tough to do well in practice. One of the most complex transitions for students and teachers to make is the move from a pedagogy that centres on individuals demonstrating their learning to a pedagogy that embraces groups demonstrating their learning. (p. 26)

"The litmus test for collaborative production is simple: no one person can take credit for what gets created and the project could not come into being without the participation of many." (Shirky, 2008, p. 50) 


\section{Collaboration in a Digital World}

The Internet has changed and continues to change the way learners connect by providing new forms of interaction and social construction. Digital technology provides for differentiation, accountability, and visibility in the learning process. Emerging approaches to digital scholarship question what knowledge is, how it is gained, and how it is shared, amongst other things. Veletsianos and Kimmons (2012) share a new form of scholarship called "Networked Participatory Scholarship" that reflects scholarly practice and participatory technologies. For collaborative learning, online technologies provide a platform for engaged learning, deeper understanding, and exciting outcomes.

Moving into the age of online collaboration means understanding the importance of contribution and shared practice, including shared research and co-creation. It also means "learning about" can become "learning with," and this is enhanced by contact either virtually or in person (or virtually in person). The video "Collaboration: On the Edge of a New Paradigm" (Collaborative Society, 2013) discusses a shift from a world about "content" to a world about "context." It shares with us the imperative of collaboration to solve global issues in health, society, science, and economics. Online collaboration offers opportunities to contribute, create, and co-create with partners at a distance and from a range of cultures while fostering global digital citizenship skills (Lindsay \& Davis, 2012).

The paradigm shift to include online collaboration as a norm is shared by Lee and Ward (2013) who state that, "while insular, 'stand alone' teaching has characterized the teaching of a paper-based world, collaborative teaching could well characterize that of an increasingly digital and networked world; a world where collaboration and integration are the norm" (p. 3). The social nature of learning and online collaboration leads to the development of a "Community of Practice" or CoP, a group of networked learners who share a craft and/or a profession (Wenger, 2000), and experiences are shaped by the many as opposed to the individual teacher (Wenger, White, \& Smith, 2009).

\section{Putting the "Global" Into Online Collaboration}

Online global collaboration, as distinct from online collaborative learning communities or technology integration, broadly refers to geographically dispersed educators, classrooms, schools, and institutions that use online learning environments and digital technologies to learn with others beyond their immediate environment to support curricular objectives, intercultural understandings, critical thinking, 
personal and social capabilities, and ICT capabilities (Lindsay, 2016). It is when global partnerships are made for the purpose of working and learning together on specific goals and co-creating new knowledge. The effective application of online global collaboration is not easy and not always achieved, nor is it generally supported by standard curriculum and assessment, both of which are traditionally focused on individual response. True online global collaboration in the digital learning environment requires a shift in teaching and learning to "flatten" the learning experience to bring the outside world in and vice versa; to build bridges for global empathy; to create workable structures where all participants can learn with and not just from each other.

\section{What if We Collaborated Globally?}

It is vital that schools and institutions develop integrated curriculum and new assessment models while pursuing opportunities for learners to adopt techno-personal skills allowing them to engage in both synchronous and asynchronous collaborative learning. Work in the future will require skills that are cross-platform, freelance and flexible, local and global. Therefore, online global collaborations must serve many purposes, including the following:

To prepare all learners to be globally competent and able to act on issues of local and global significance. Global collaborations allow people to frame their understanding of the world through connected experiences that go beyond the typical textbook approach and the limitations of face-to-face or local interactions. Such collaborations can turn intercultural differences into intercultural understandings by breaking down stereotypes and challenging attitudes of cultural superiority and socioeconomic dominance.

To provide a focus for digital and online technologies. As a disruptive, immersive, and ongoing innovation, online global collaborations build on new tools for mobile and ubiquitous computing. As students engage in online collaborations, they gain an understanding of the power of technology to benefit humanity.

To create a new paradigm for modern learning. Connected learning pedagogies challenge isolation and change the way we teach and learn. An "unflat," non-collaborative learning environment is disconnected and isolated. Learners must be able to go beyond the "textbook" to connect, not just with current content, but also with people who are the voice-peers, experts, and online communities building collaborations for deeper understanding of the world. 
To support glocalization. Online global collaboration across disciplines and learning modes supports true glocalization and a "think global and act local" mantra. Glocalization is about accepting differences and applying to the local context without homogenization. The goal is not for one culture to emerge, but to find differences as well as commonalities.

\section{New Pedagogical Approaches}

Pedagogical capacity, an educator's repertoire of teaching strategies and partnerships for learning, has and will continue to change as technology becomes more pervasive to include content delivery and consumption as well as collaboration and creation of new knowledge and a focus on the process of learning (Fullan et al., 2014). The advent of new technologies in the classroom or learning environment has not necessarily changed pedagogy. A multiple case study research design employed by Ertmer, Ottenbreit-Leftwich, Sadik, Sendurur, and Sendurur (2012) examined similarities and differences among pedagogical beliefs and technology practices of educators using emerging technologies. Results suggest knowledge and skills as well as attitudes and beliefs (described as second-order barriers) - and not hardware, software, and networking issues (known as first-order barriers) - are the gatekeepers to better use of technology for learning. Greenhow, Robelia, and Hughes (2009) found similar barriers and enablers to learning using Web 2.0 technologies. Fullan and colleagues (2014) shares the research of John Hattie where in the new pedagogies an educator has a new role as activator, including educator-student relationship, reciprocal teaching, and feedback.

It is possible that online global collaboration affords new pedagogical approaches. If we understand pedagogy to mean the method and practice of teaching, especially as an academic subject or theoretical concept, then perhaps it is time to consider a new approach that informs the art and science of teaching and learning across the world while using online technologies. In addition, the discussion about leading pedagogical change in the context of our digital and online world would perhaps benefit from an infusion of new terms to help align with the goals of global, connected, and "flat" learning. In his book "Open," David Price (2013) discusses the shift from pedagogy (to lead the child: "instructional learning"), to andragogy (to lead the man/adult: "self-directed learning"), to heutagogy (to lead to find: "self-determined learning"). Heutagogy has been applied to adult education, as described by originators Hase and Kenyon (2000). Additionally, peeragogy (Rheingold, 2012), an open learning environment and a new way of seeing, collaborating, and learning, is often unstructured in practice; learning is collaborative and supports knowledge building amongst learners in a Community of Practice (CoP). 
A flat and connected learning environment where participants collaborate globally requires that educators take a different and what I have coined as a "cosmogogical" approach. The term "cosmogogy" applies to teaching and learning while having a global or a world approach. It means comfortable and familiar learning with others in different places through online technologies. It puts the learner at the center of the "universe," a node on the network, with the capability of reaching out and connecting to anything and anyone to find information, in order to collaborate and to co-create with anyone, anywhere, anytime. It also means learners approach problems and solutions from a more openly networked and, in fact, global perspective to the point that "unflat" learning feels strange and closed in. Cosmogogy can be adopted as a pedagogy and as a curriculum approach.

To make the move from local to global learning modes, it is imperative to understand the digital collaborative and global communication paradigm. Maximize the use of online technologies, foster networked communities, embrace blended learning modes and "flat" connected pedagogy (cosmogogy), and empower learners for autonomous online global collaborations. Not only must the teacher become the activator in this, the student becomes the active learner, the institution becomes the conduit to collaboration, and community members and groups become partners in learning.

\section{The Future Is Now}

It's time for education leaders, educators, parents, and students to take ownership of digital learning, and not just "dabble on the edges." It's time to cut through some of the barriers preventing true global learning-technology access, curriculum constraints, fear of the unknown, lack of pedagogical knowledge-and realize that the world is flat and connected and how we learn is the same. It's time to better understand and implement student self-determined learning that is connected and collaborative-as we say, students are the best textbook for each other. Be active, be available, be approachable, be agile. Develop a plan around the vision that all learners at all levels will have many interdisciplinary global learning experiences with others beyond their immediate environment-and have the technological access and fluency to do this. Let's not ignore the collaborative learning possibilities afforded by new realities and approaches. It is already happening-solutions to global issues are being discussed and shared across all levels of learning-make sure you are a part of this! In fact, it is the dawn of a new era: We have the technology; we have the pedagogy_it's time to connect the world. 


\section{References}

Collaborative Society. (2013). Collaboration - on the edge of a new paradigm [video file]. Retrieved from https://vimeo.com/77240879

Dillenbourg, P. (1999). What do you mean by collaborative learning? In P. Dillenbourg (Ed.), Collaborative-learning: Cognitive and computational approaches (pp. 1-19). Oxford, UK: Elsevier.

Downes, S. (2006). Learning networks and connective knowledge. Retrieved from http://itforum.coe.uga.edu/AECT_ITF_PDFS/ paper92.pdf.

Downes, S. (2007). An introduction to connective knowledge. Paper presented at the Media, Knowledge \& Education - Exploring new spaces, relations and dynamics in digital media ecologies. Retrieved from http://www.downes.ca/cgi-bin/page.cgi? post $=33034$

Downes, S. (2008). Places to go: Connectivism \& connective knowledge. Innovate: Journal of Online Education, 5(1), 1-6.

Downes, S. (2014, April 21). Connectivism as learning theory [Blog post]. Retrieved from http://halfanhour.blogspot.com.au/2014 /04/connectivism-as-learning-theory.html

Ertmer, P. A., Ottenbreit-Leftwich, A. T., Sadik, O., Sendurur, E., \& Sendurur, P. (2012). Teacher beliefs and technology integration practices: A critical relationship. Computers \& Education, 59(2), 423-435.

Friedman, T. (2007). The world is flat 3.0: A brief history of the XXI century. New York: Picador.

Fullan, M., Langworthy, M., \& Barber, M. (2014). A rich seam: How new pedagogies find deep learning. London: Pearson.

Gore, A. (2013). The future. New York: Random House.

Greenhow, C., Robelia, B., \& Hughes, J. E. (2009). Learning, teaching, and scholarship in a digital age web 2.0 and classroom research: What path should we take now? Educational Researcher, 38(4), 246-259.

Hase, S., \& Kenyon, C. (2000). From andragogy to heutagogy. Ultibase Articles, 5(3), 1-10.
Laurillard, D. (2009). The pedagogical challenges to collaborative technologies. International Journal of Computer-Supported Collaborative Learning, 4(1), 5-20.

Laurillard, D. (2012). Teaching as a design science: Building pedagogical patterns for learning and technology. New York: Routledge.

Lee, M., \& Ward, L. (2013). Collaboration in learning: Transcending the classroom walls. Camberwell, Victoria: ACER Press.

Lindsay, J., \& Davis, V. (2012). Flattening classrooms, engaging minds: Move to global collaboration one step at a time. New York: Allyn and Bacon.

Lindsay, J. (2016). The global educator: Leveraging technology for collaborative learning \& teaching. Eugene, Oregon/Arlington, VA: International Society for Technology in Education.

McLoughlin, C., \& Lee, M. J. (2010). Personalised and self regulated learning in the Web 2.0 era: International exemplars of innovative pedagogy using social software. Australasian Journal of Educational Technology, 26(1), 28-43.

Paterson, C. (2013, October 29). What's the other story? [Blog post]. Retrieved from http://learningshore.edublogsorg/2013/ 10/29/whats-the-other-story/

Piaget, J. (1929). The child's conception of the world. United States of America: Rowman \& Littlefield.

Price, D. (2013). Open: How we'll work, live and learn in the future. United Kingdom: Crux Publishing.

Rheingold, H. (2012). Toward peeragogy. DML Central, 23. Retrieved from http://dmlcentral.net/toward-peeragogy/

Shirky, C. (2008). Here comes everybody: The power of organizing without organizations. UK: Penguin.

Siemens, G. (2005). Connectivism: A learning theory for the digital age. Retrieved from http://www.elearnspace.org/Articles/ connectivism.htm 
Siemens, G. (2006). Learning in Synch with Life: New Models, New Processes. White paper for Google.

Veletsianos, G., \& Kimmons, R. (2012). Networked participatory scholarship: Emergent technocultural pressures toward open and digital scholarship in online networks. Computers \& Education, 58(2), 766-774.

Vygotsky, L. S. (1978). Mind in society: The development of higher psychological processes. Cambridge, UK: Harvard University Press.
Wenger, E. (2000). Communities of practice and social learning systems. Organization, 7(2), 225-246.

Wenger, E., White, N., \& Smith, J. D. (2009). Digital habitats: Stewarding technology for communities. Portland, OR: CPsquare.

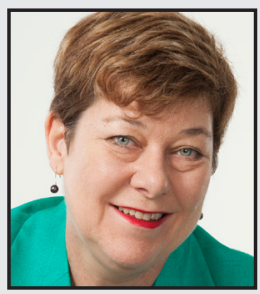

Julie Lindsay has worked as an educational technology leader in K-12 schools in Australia, Asia, Africa, and the Middle East. As Founder and CEO of Flat Connections, she designs and manages online global projects for all K-12 levels and customizes virtual courses for educators. She also works at Charles Sturt University as an Adjunct Lecturer and is the Quality Learning and Teaching Leader (online) in the Faculty of Arts and Education. Her PhD research with the University of Southern Queensland is about online global educators and pedagogical change. Julie's latest book, "The Global Educator: Leveraging Technology for Collaborative Learning and Teaching" (ISTE, 2016), shares approaches, updated practices, and case studies on how to learn and collaborate online both locally and globally. 